\title{
Effect of extremes of temperature and humidity on the goblet cell count in the rat airway epithelium
}

\author{
ROSEMARY JONES, ANNA M. BAETJER ${ }^{1}$, and LYNNE REID \\ Department of Experimental Pathology, Institute of Diseases of the Chest, \\ Brompton Hospital, London S.W.3
}

\begin{abstract}
Jones, R., Baetjer, A. M., and Reid, L. (1971). Brit. J. industr. Med., 28, 369-373. Effect of extremes of temperature and humidity on the goblet cell count in the rat airway epithelium. To investigate the effect of environmental temperature and humidity on the goblet cells in the rat airway epithelium, eight animals were exposed for four to five weeks to each of the following conditions: normal; hot-moist or tropical; hot-dry or desert; and cold. The animals in the three groups exposed to abnormal atmospheric conditions failed to gain weight as fast as those in the control group. No increase in the number or area of goblet cells was found in any group, although with irritants previously tested, such as tobacco smoke, a marked increase has been found in this time. It would seem that climatic effects are much less important than irritation in the production of hypertrophy and hyperplasia of mucus-secreting cells, the hallmark of chronic bronchitis.
\end{abstract}

An increase in the number of goblet cells of the surface epithelium of the lung and hypertrophy of the mucous glands in the bronchial wall are characteristic pathological features of chronic bronchitis (Reid, 1954, 1960). The same changes have been produced by a variety of irritants including sulphur dioxide (Reid, 1963; Lamb and Reid, 1968), nitrous oxide (Freeman and Haydon, 1964), and tobacco smoke (Lamb and Reid, 1969). Counting goblet cells in the surface epithelium and measuring gland size are sensitive and precise ways of measuring the effect of environmental conditions on the surface epithelium.

The effect of irritants has also been investigated epidemiologically, and tobacco smoke has been shown to be the most important cause of chronic bronchitis in the adult population (Oswald and Medvei, 1955; Royal College of Physicians of

${ }^{1}$ Johns Hopkins University,

School of Hygiene and Public Health, Baltimore,

Maryland, U.S.A.
London, 1971). Chronic bronchitis has for long been known as the English disease but recent international studies suggest that if there is agreement in the definition of chronic bronchitis there is little difference in prevalence. It may be that there is a difference in severity of the disease and suspicion lingers that climatic conditions may play some part. It is tempting to accept that the fogs so characteristic of the climate of the United Kingdom are not without this hazard.

The purpose of the work reported in this paper was to investigate the effect of temperature and humidity on the number of goblet cells in the rat airway epithelium as this would offer a way of investigating any possible contribution by environmental conditions to the development of chronic bronchitis.

These experiments were carried out jointly by the Department of Environmental Medicine, School of Hygiene and Public Health, The Johns Hopkins University, Baltimore, where facilities for the control of conditions of temperature and humidity were 
available, and the Department of Experimental Pathology, Institute of Diseases of the Chest, where assessment of the biological effect was made.

\section{Materials and methods}

The rat was used for these experiments since, even when healthy, it is endowed with more goblet cells and glands than other small rodents. It is necessary to ensure that the lungs of these animals are free of infection and we have increasingly come to accept as the most satisfactory test the histological criterion of absence of lymphocytic infiltration (Reid, 1970). Considerable difficulty was encountered in securing rats which exhibited no lymphocytic infiltration. After testing four strains which proved unsatisfactory a pathogen-free Wistar strain from Manor Farms, San Juan, Puerto Rico, was found to be suitable for these experiments.

Thirty-two 17-g rats were maintained for two weeks after delivery in a stock room used exclusively for this strain, after which period of adjustment they were divided into four groups and placed in temperature and humidity controlled exposure chambers. The four chambers were supplied from the same source of air but were adjusted to provide normal, hot-moist or tropical, hot dry or desert, and cold conditions respectively. The specific exposure conditions, shown in Table 1, were chosen because they represented low and high temperatures to which rats can adapt physiologically. Each rat was kept in a separate cage within the exposure chamber. The rats were fed a dry pellet diet sold under the trade name 'Rockland Rat Diet'. Water was supplied from a glass bottle and tube; food and water were freely available throughout the day and night. The amount consumed was not measured. The animals in each group were weighed at the beginning and end of exposure, and all except the 'hot dry group' were weighed in the middle of the exposure period as well.

The dry and wet bulb temperatures were recorded twice daily from thermistors. Exposure to the experimental conditions was continuous, the chambers being opened only for feeding, watering, and cleaning. Exposure continued for between 32 and 34 days. Over a period of three days animals were killed in rotation from each group.

The rats were killed with intraperitoneal sodium pentobarbital and the trachea and the lungs were removed en bloc. Buffered formol saline was injected into the trachea until both lungs were inflated and with a tense pleura. The trachea was tied with cotton thread to which long ends were left so that these could be used to stretch the trachea over card to its original length; the specimen was then dropped into a jar of formol saline for fixation. At least one week later each set of lungs was packed into a small plastic bag with about $5 \mathrm{ml}$ of formalin and in this way they were transported from the United States of America to the United Kingdom. Sections were cut transversely and longitudinally through the trachea and through the left lung so that the sections included as much of its axial airway as possible.

When the light microscopic count was unsatisfactory, the blocks were re-cut and stained with alcian blue for examination with the Quantimet (Mawdesley-Thomas and Healey, 1969). With the Quantimet, from each case 1,000 fields (each field $160 \mu \mathrm{m}$ in diameter) of the trachea and intrapulmonary airways were scanned for each animal. The trachea was satisfactory in all animals but not enough fields were available for airway counts in 1, 3,5 , and 2 animals of groups I to IV respectively.

\section{Results}

\section{Weight gain}

The pattern of weight gain for the four groups is shown in Table 2. None of the three experimental groups gained weight to anything like the same extent as the control group but there was no significant difference between the exposure groups. In the two groups weighed during the experiment, the slower weight gain was already apparent, although it was more marked as the exposure proceeded.

\section{Goblet cell count}

Since analysis of the results obtained with the light microscope showed that the difference between the groups was not significant, the Quantimet Image Analyser was used to count the area of the tracheal epithelium which stained for acid glycoprotein with the alcian blue stain and also the number of separate areas of such material. Such an area might represent just one goblet cell or several continuous cells. This was done for the trachea separately from the intratracheal airways. In Table 3, the difference between each experimental group is given, the control group, the standard error of difference, and the result of the $t$ test, showing no significant difference between them. The means of the deviations are negative save in the trachea where, after exposure to hot-dry conditions, the increase was positive.

TABLE 1

Environmental Conditions Tested

\begin{tabular}{|c|c|c|c|c|c|}
\hline & & Control & Hot-wet & Hot-dry & Cold \\
\hline $\begin{array}{l}\text { Dry bulb }\left({ }^{\circ} \mathrm{C}\right) \\
\text { Wet bulb }\left({ }^{\circ} \mathrm{C}\right) \\
\text { Vapour pressure }(\mathrm{mmHg}) \\
\text { Relative humidity }(\%)\end{array}$ & $\begin{array}{l}\cdots \\
\cdots \\
\cdots \\
\cdots\end{array}$ & $\begin{array}{c}22 \cdot 8-23 \cdot 9 \\
10 \cdot 0-16 \cdot 7 \\
3-11 \\
11-50\end{array}$ & $\begin{array}{c}32 \cdot 2-32 \cdot 8 \\
30 \cdot 0-30 \cdot 6 \\
31 \\
85\end{array}$ & $\begin{array}{c}32 \cdot 2-32 \cdot 8 \\
13 \cdot 3-13 \cdot 9 \\
3 \\
5\end{array}$ & $\begin{array}{c}6 \cdot 7-8 \cdot 9 \\
3 \cdot 3-4 \cdot 4 \\
4 \\
52\end{array}$ \\
\hline
\end{tabular}


TABLE 2

WeIGHT GAIN

\begin{tabular}{|c|c|c|c|c|c|c|c|c|c|c|c|c|c|}
\hline \multirow{3}{*}{ Time } & & \multicolumn{3}{|c|}{ Control } & \multicolumn{3}{|c|}{ Hot-wet } & \multicolumn{3}{|c|}{ Hot-dry } & \multicolumn{3}{|c|}{ Cold } \\
\hline & & \multirow{2}{*}{$\begin{array}{c}\text { Mean } \\
\text { weight } \\
(g)\end{array}$} & \multicolumn{2}{|c|}{ Gain } & \multirow{2}{*}{$\begin{array}{c}\text { Mean } \\
\text { weight } \\
(g)\end{array}$} & \multicolumn{2}{|c|}{ Gain } & \multirow{2}{*}{$\begin{array}{c}\text { Mean } \\
\text { weight } \\
(g)\end{array}$} & \multicolumn{2}{|c|}{ Gain } & \multirow{2}{*}{$\begin{array}{c}\text { Mean } \\
\text { weight } \\
(\mathrm{g})\end{array}$} & \multicolumn{2}{|c|}{ Gain } \\
\hline & & & Actual & $\%$ & & Actual & $\%$ & & Actual & $\%$ & & Actual & $\%$ \\
\hline $\begin{array}{l}\text { Before exposure } \\
\text { After } 2 \text { weeks }\end{array}$ & $\begin{array}{l}\cdots \\
\cdots\end{array}$ & $\begin{array}{l}167 \\
262\end{array}$ & 95 & $56 \cdot 9$ & $\begin{array}{l}167 \\
239\end{array}$ & 72 & $43 \cdot 1$ & & & & $\begin{array}{l}168 \\
240\end{array}$ & 72 & $42 \cdot 9$ \\
\hline At end $\quad \ldots$ & . & 340 & 173 & $103 \cdot 6$ & 297 & 130 & $77 \cdot 8$ & 293 & 128 & $77 \cdot 6$ & 299 & 131 & $78 \cdot 0$ \\
\hline
\end{tabular}

The standard error of mean weight, as a percentage of this mean, is nowhere greater than 3 and often less than 2; the standard error of weight gain, again as a percentage, is only once slightly in excess of $6 \%$-in the 'cold' group. Because of these small standard errors the weight gains can be taken broadly at their face value.

TABLE 3

Effect of Temperature and Humidity on Goblet Cell Number and Area

\begin{tabular}{|c|c|c|c|c|c|c|c|}
\hline & & & & $\begin{array}{c}\text { Mean } \\
\text { count }(C) \text { and } \\
\text { area }(A)\end{array}$ & $\begin{array}{l}\text { Difference } \\
\text { from } \\
\text { normal }\end{array}$ & $\begin{array}{l}\text { Standard } \\
\text { error of } \\
\text { difference }\end{array}$ & $\mathrm{t}$ test $^{1}$ \\
\hline \multicolumn{8}{|l|}{ Normal } \\
\hline & A & $\begin{array}{l}\cdots \\
\cdots\end{array}$ & .. & $\begin{array}{r}0.21 \\
2.26\end{array}$ & & & \\
\hline \multirow[t]{2}{*}{ Bronchiolus } & C & .. & .. & $64 \cdot 28$ & & & \\
\hline & A & .. & .. & $2 \cdot 74$ & & & \\
\hline \multicolumn{8}{|l|}{ Hot-wet } \\
\hline Trachea & C & .. & .. & 31.75 & $-7 \cdot 13$ & 12.45 & 0.57 \\
\hline \multirow{3}{*}{ Bronchiolus } & A & .. & .. & 1.87 & -0.38 & 0.69 & 0.56 \\
\hline & C & .. & .. & $71 \cdot 80$ & +7.51 & 25.06 & $0 \cdot 30$ \\
\hline & A & .. & .. & 2.67 & -0.07 & $1 \cdot 14$ & 0.06 \\
\hline \multicolumn{8}{|l|}{ Hot-dry } \\
\hline Trachea & C & .. & .. & $59 \cdot 43$ & +20.55 & 14.80 & 1.39 \\
\hline \multirow{3}{*}{ Bronchiolus } & A & .. & .. & 4.01 & +1.74 & 1.05 & 1.66 \\
\hline & C & .. & .. & $28 \cdot 33$ & $-35 \cdot 96$ & $21 \cdot 73$ & 1.66 \\
\hline & $\mathbf{A}$ & .. & .. & 0.94 & -1.80 & $1 \cdot 18$ & $1 \cdot 52$ \\
\hline \multicolumn{8}{|l|}{ Cold } \\
\hline \multirow[t]{2}{*}{ Trachea } & C & .. & .. & 32.00 & -6.88 & $10 \cdot 32$ & 0.67 \\
\hline & A & .. & & 2.05 & -0.21 & 0.62 & 0.34 \\
\hline \multirow[t]{2}{*}{ Bronchiolus } & C & .. & .. & $45 \cdot 67$ & $-18 \cdot 62$ & $25 \cdot 51$ & 0.73 \\
\hline & $\mathbf{A}$ & .. & .. & 1.32 & -1.42 & $1 \cdot 17$ & $1 \cdot 21$ \\
\hline
\end{tabular}

${ }^{2}$ None of these values is significant

\section{Discussion}

The results from this experiment are negative in that the conditions of humidity and temperature applied over a five-week exposure period produced no significant increase in the number of goblet cells. The conditions under test do offer an extreme range of humidity and temperature. It is considered justified to report these negative results in order that they might be compared with similar experiments carried out with irritants.

It is felt that a higher humidity in the cold chamber would have had no significant effect on water or heat loss from the surface of tissue. The vapour pressure in the chamber was $4 \mathrm{mmHg}$. With complete saturation at these temperatures the vapour pressure would be 7 to $8 \mathrm{mmHg}$. Evaporation of water vapour from a wet surface depends on the difference in the vapour pressure of the air and the vapour pressure at the surface. If it is assumed that the temperatures of the trachea and bronchi are equal to the normal rectal temperature of rats $\left(37.5^{\circ} \mathrm{C}\right)$ and that the surface air over the airways is saturated, the vapour pressure at the surface would be $48 \mathrm{mmHg}$. Thus the vapour 
pressure gradient between the surface and the air would be $44 \mathrm{~mm}$ with a $4 \mathrm{~mm}$ vapour pressure in the air, and $40 \mathrm{~mm}$ with an $8 \mathrm{~mm}$ vapour pressure. With such a large vapour pressure gradient between the surface and the air, the difference between a $56 \%$ relative humidity and $100 \%$ relative humidity would be insignificant in considering water or heat loss from the surface of the tissue.

The method of detecting an effect on the bronchial epithelium is sensitive since exposure to five cigarettes a day for even three weeks has produced a significant increase in goblet cells (Lamb and Reid, 1969). These results were obtained with the light microscope on fewer fields than were included in the present analysis, whose sensitivity was even greater because of the larger number of fields studied by the automated image analyser (Mawdesley-Thomas and Healey, 1969). From experiments reported here it seems justified to conclude that in the rat any effect of temperature and humidity is so slight as to be unimportant when compared with the irritants which commonly assail the bronchial tree.

The animals exposed to either the hot or cold temperature gained weight more slowly than did the control animals. For both temperature groups the weight gain was lower but similar regardless of the relative humidity, but it is probable that the reason for the reduced weight gain was a difference in the two temperature groups. Leblond and Gross (1943) reported that 'food intake and growth rate and activity of rat is markedly reduced at $35^{\circ} \mathrm{C}$ '. Dempsey and Astwood (1943) have reported that $32^{\circ} \mathrm{C}$ is the actual temperature above which the rat cannot control its body temperature: in the experiments reported here the animals were exposed to about $32 \cdot 5^{\circ} \mathrm{C}$

Animals show an increased metabolic rate when exposed below a critical temperature (Burton and Edholm, 1955). Its effect on weight will vary with the food intake. In the cold exposures reported here, the temperature was not so extreme that there was a loss of weight but the gain was less than that of the controls. Loss of weight on exposure to cold was reported by Katsh, Katsh, and Osher (1954); Cottle and Carlson (1954), Dugal and Thérien (1949), and Leblond and Gross (1943) are among those who have reported lower weight gain on exposure to cold.

Smoking is one of the more effective irritants in producing hypertrophy of mucus-secreting tissue and it may be that any hypertrophy produced by changes in humidity and temperature would take very much longer to appear. Recent epidemiological studies suggest that coal dust, for example, may contribute to the development of chronic bronchitis, but this can be detected only after many years of exposure to dust (Jacobsen, Rae, Walton, and Rogan, 1970).
The experiments reported here are concerned only with the development of chronic bronchitis and it cannot be denied that excessive atmospheric humidity or dryness may be significant in a patient who is already a bronchitic and therefore secreting an excessive amount of mucus. It is known, for example, that the ciliary mucus clearance rate is affected by temperature, increasing with a rise in temperature over an optimum range (Dalhamn, 1956; Baetjer, 1967). The recent experiments of Baetjer (1967) have shown also that the mucus clearance rate is inversely proportional to the temperature of the trachea over the previous $\mathbf{4 8}$ hours. Such acclimatization experiments may be expected to throw further light on the problems in human disease.

We are grateful to Dr. Lionel Mawdesley-Thomas and Mr. Peter Healey of the Huntingdon Research Centre for carrying out the Quantimet studies. Our thanks are due to Dr. Bernard Benjamin for the statistical analysis. This work was supported by a grant from the National Coal Board. A.B. was supported by U.S.F. H.S. grant No. 1-R01-ES00373-01.

\section{References}

Baetjer, A. M. (1967). Effect of ambient temperature and vapor pressure on cilia-mucus clearance rate. J. appl. Physiol., 23, 498-504.

Burton, A. C., and Edholm, O. G. (1955). Man in a Cold Environment, p. 166. Edward Arnold, London. (Monographs of the Physiological Society, No. 2).

Cottle, W., and Carlson, L. D. (1954). Adaptive changes in rats exposed to cold. Caloric exchange. Amer. J. Physiol., 178, 305-308.

Dalhamn, T. (1956). Mucous flow and ciliary activity in the trachea of healthy rats and rats exposed to respiratory irritant gases $\left(\mathrm{SO}_{2}, \mathrm{H}_{3} \mathrm{~N}, \mathrm{HCHO}\right)$. Acta physiol. scand., 36, Suppl. 123.

Dempsey, E. W., and Astwood, E. B. (1943). Determination of the rate of thyroid hormone secretion at various environmental temperatures. Endocrinology, 32, 509-518.

Dugal, L. P., and Thérien, M. (1949). The influence of ascorbic acid on the adrenal weight during exposure to cold. Endocrinology, 44, 420-426.

Freeman, G., and Haydon, G. B. (1964). Emphysema after low-level exposure to $\mathrm{NO}_{2}$. Arch. environm. Hlth, 8, 125128.

Jacobsen, M., Rae, S., Walton, W. H., and Rogan, J. M. (1970). New dust standards for British coal mines. Nature (Lond.), 227, 445-447.

Katsh, S., Katsh, G. F., and Osher, P. (1954). Adrenal, pituitary and urinary ascorbic acid levels in rats subjected to hypothermic environment. Amer. J. Physiol., 178, 457-461.

Lamb, D., and Reid, L. (1968). Mitotic rates, goblet cell increase and histochemical changes in mucus in rat bronchial epithelium during exposure to sulphur dioxide. J. Path. Bact., 96, 97-111.

- - (1969). Goblet cell increase in rat bronchial epithelium after exposure to cigarette and cigar tobacco smoke. Brit. med. J., 1, 33-35.

Leblond, C. P., and Gross, J. (1943). Effect of thyroidectomy on resistance to low environmental temperature. Endocrinology, 33, 155-160. 
Mawdesley-Thomas, L. E., and Healey, P. (1969). Automated analysis of cellular change in histological sections. Science, 163, 1200.

Oswald, N. C., and Medvei, V. C. (1955). Chronic bronchitis: the effect of cigarette-smoking. Lancet, 2, 843-844.

Reid, L. A. (1954). Pathology of chronic bronchitis. Lancet, 1, 275-278.

(1960). Measurement of the bronchial mucous gland layer: a diagnostic yardstick in chronic bronchitis. Thorax, 15, 132-141.
(1963). An experimental study of hypersecretion of mucus in the bronchial tree. Brit. J. exp. Path., 44, 437445.

(1970). Evaluation of model systems for study of airway epithelium cilia, and mucus. Arch. intern. Med., 126, 428-434.

Royal College of Physicians of London (1971). Smoking and Health Now. Pitman Medical and Scientific Publishing Co., London.

Received for publication March 4, 1971 